\title{
New observations on a Pridoli plant assemblage from north Xinjiang, northwest China, with comments on its evolutionary and palaeogeographical significance
}

\author{
CAI CHONG-YANG*, DOU YA-WEI $\&$ D. EDWARDS $\ddagger$
}

* Nanjing Institute of Geology and Palaeontology, Academia Sinica, Chi-Ming-Ssu, Nanjing, 210008, China

$\dagger$ Third Institute of Oceanography, National Bureau of Oceanography, 361005, Xiamen, Fujian, China

$\ddagger$ Department of Geology, University of Wales College of Cardiff, P.O. Box 914, Cardiff CFI 3YE, U.K.

(Received 17 February 1992; accepted 30 June 1992)

\begin{abstract}
Detailed descriptions of plant remains from a late Silurian (Pridoli) locality in Xinjiang Province, northwest China are presented. They include Junggaria spinosa Dou, interpreted as identical with Cooksonella sphaerica Senkevich, Salopella xingjiangensis Dou, and a number of sterile axes, including one with a leafy appearance superficially resembling a lycophyte, and others of probable algal affinity. Lack of anatomical and reproductive characteristics precludes a more precise assessment of relationships. A justification for the Pridoli rather than Lower Devonian age of the assemblage is based on graptolites. The composition of the assemblage is compared with coeval ones from Europe, North America, north Africa and Kazakhstan and has closest similarities with the latter. Palaeogeographic proximity on the Kazakhstan palaeocontinent is postulated, but the dearth of global Silurian occurrences of land plants make it premature to evaluate the significance of Kazakhstan and Chinese assemblages in terms of global provincialism in the late Silurian. The most distinctive element in these assemblages (Junggaria/Cooksonella) has sporangia with more complex, indeed more enigmatic organization, than seen in most Silurian and early Devonian rhyniophytoids.
\end{abstract}

\section{Introduction}

That occurrences of Silurian land plants are rare and that the record is severely biased towards the present circum-north Atlantic region have almost become platitudes. The limitations of basing evolutionary and palaeophytogeographical hypotheses on such evidence are very well illustrated by reference to late Silurian assemblages in Australia, where some plants are strikingly different in morphology and affinity from their coeval present-day northern hemisphere counterparts. Here we present a detailed report of a small assemblage from Xinjiang, northwest China which was originally determined to be early Devonian, but on reassessment of associated graptolites is now considered late Silurian. It is the first record of Pridoli plants from China.

Silurian and Lower Devonian rocks are wellexposed in the Junggar Basin of north Xinjiang (Hou et al. 1979; Zheng \& Xiao, 1979; Lin et al. 1984; He, 1988), correlation being facilitated by abundant faunas. Considering the Silurian record, although graptolite facies predominate in older rocks and shelly facies in younger, in certain areas the faunas are mixed (section 7). The plants are interbedded with graptolites, the latter providing a more secure foundation for age determination than the plants themselves.

\section{Previous research}

Plant fossils were discovered in 1973 by a stratigraphical survey team from the Bureau of Geology, Xinjiang, and the Geological Institute, Academy of Sciences, Beijing. The new taxon Junggaria spinosa, new species Salopella xinjiangensis and Sciadophyton pristinum together with Zosterophyllum sp. were subsequently described by Dou (in Dou \& Sun, 1983) from the middle part of the Wutubulake Formation then considered Gedinnian from graptolites and the plants themselves. Following further collecting from the same strata Dou and Sun added Parka, Algites, Thallites, Hostinella, Psilophytites and a fragmentary lycophyte to the species list but gave no descriptions. They named the assemblage the ZosterophyllumJunggaria Assemblage of Lower Devonian age. They also found additional algae and a fragment of lycophyte at Santanhu, Barkol, Kazak Autonomous County in the eastern part of the Junggar Basin. The type section of the Wutubulake Formation was reinvestigated by Cai and colleagues in 1985, when they collected further plants and invertebrates, including most importantly some of the graptolites used for the new correlation. Hou, Gong and Cai returned in 1988 and found more plants and salient graptolites confirming the age determination as Pridoli. 


\section{Stratigraphy and correlation}

Upper Silurian and Lower Devonian rocks in north Xinjiang have been divided into the Kekexiongkuduke Formation and the Hoboksar Group, with three comformable formations, the Mongkelu, Mangeer and Wutubulake, distinguished in the latter. The main plant assemblage occurs in the middle part of the Wutubulake Formation located at Mongkelu c. $18 \mathrm{~km}$ east of Wutubulak, Hoboksar, Mongolia Autonomous County, west Junggar Basin (Fig. 1).

A detailed section of the Wutubulake Formation is presented in Figure 2: the numbers $1-5$ relate to the description in Table 1. The second column is a measured section through the plant and graptolite bearing beds.

\section{3.a. Age}

The Hoboksar Group was originally considered to be entirely in the Lower Devonian, with the age of the plant-bearing beds in the Wutubulake Formation identified as Gedinnian on the basis of the contained plants (Salopella, and most particularly, Zosterophyllum) and of graptolites, named Monograptus exiguus, $M$. junggarensis and $M$. varithecatus by Qiao (Lee \& Tsai (Li \& Cai)), 1978; Qiao, 1983; Dou \& Sun, 1983, 1985). More recently collected graptolites identified by Chen and $\mathrm{Ni}$ as $M$. anerosus Koren' (AEJ 308a) and M. mironovi Koren' (AEJ 307) suggested on the basis of Koren's work (Koren', 1983) in neighbouring Kazakhstan that the fossiliferous horizons occur near the top of the Pridoli and approximate to the $M$. bouceki and $M$. perneri zones (cf. Rong \& Chen, 1992; Cai \& Li in press; Fig. 3). Rickards (pers. comm.) supported the Pridoli determination when he identified three further graptolites as $M$. cf. anerosus Koren' (88W-6 upper), $M$. aff. transgrediens Perner (88W-1) and $M$. ?pridoliensis Pribyl (88W-1). Koren' subsequently confirmed the first (from its counterpart) as $M$. anerosus, but identified the second as Pseudomonoclimacis bandaletovi again on the counterpart (Koren' pers. comm.). Both species characterize the middle to upper part of the Tokrau horizon (Nikitin \& Bandaletov, 1986) in Kazakhstan which correlates with the mid-Pridoli (bouceki/bandaletovi zones). Of the three species erected by Qiao, she considered $M$. varithecatus synonomous with $M$. beatus Koren' and $M$. junggarensis with $M$. anerosus Koren' while $M$. exiguus is possibly $M$. cf. lochkovensis Pribyl.

Spores isolated from beds roughly correlating with the middle part of 4 in Figure 2, identified by Lu (pers. comm.) as including Ambitisporites avitus Hoffmeister, A. dilutus (Hoffmeister) Richardson and Lister, Archaeozonotriletes chulus (Cramer) Richardson and Lister var. nanus Richardson and Lister, Synorisporites libycus Richardson and Ioannides, Retuso- triletes warringtonii Richardson and Lister, are consistent with a Pridoli age, although the ranges of individual taxa extend down into the Silurian (Richardson \& McGregor, 1986) and up into the Devonian.

The single chitinozoan taxon, Angochitina cf. echinata occurs (and was hitherto known only) in Sweden in late Ludlow strata (Bohemograptus and Ozarkodina crispa Biozones) and extends into the lower Pridoli (Geng \& Li, 1984).

The brachiopods are less helpful stratigraphically as those in 4 occur in both the Upper Silurian and Lower Devonian. Indeed the position of the SilurianDevonian boundary, if indeed within the Wutubulake Formation, remains conjectural, as approximately one hundred metres of rock above the plant and graptolitebearing beds are unfossiliferous.

\section{Material and methods}

The fossils are predominantly coalified compressions with organic matter forming a continuous sheet or occurring as granules. They are preserved in buff to grey indurated sandstones, often with high organic content, and show no preferred orientation. Tangled masses of presumed drifted remains consist of a mixture of taxa, the most common being sterile axes. The preservation of fine hairs suggests that transport distances were short. Some axes are superficially striated and occasionally show elongate cells where lumina are filled with limonite. However conventional palaeobotanical techniques (e.g. film pulls, maceration) failed to reveal further details of cells. Some specimens were developed by removing rock grains using tungsten needles before photography. The latter proved difficult as there was often little contrast between the fossil and matrix.

\section{Descriptions and discussion of the assemblage}

\section{5.a. Junggaria spinosa Dou $=$ Cooksonella sphaerica} Senkevich (Figs 4a, b; 5; 6a-l)

Dou's original description (in Dou \& Sun, 1983, pl. 189, figs 1-4) although based on only four specimens indicated a far greater complexity in organization, as measured by branching pattern, sporangial arrangement and morphology, than hitherto recorded in Pridoli rhyniophytoids. The new material confirms and extends the original description. A summary of dimensions is given in Table 2 .

\section{5.a.I. Description}

The longer and presumably more complete specimens show pseudomonopodial branching with sporangia terminating up to twice isotomosing lateral branch systems, the latter being about $1.5 \mathrm{~cm}$ long. In some instances, two consecutive lateral branches are borne 


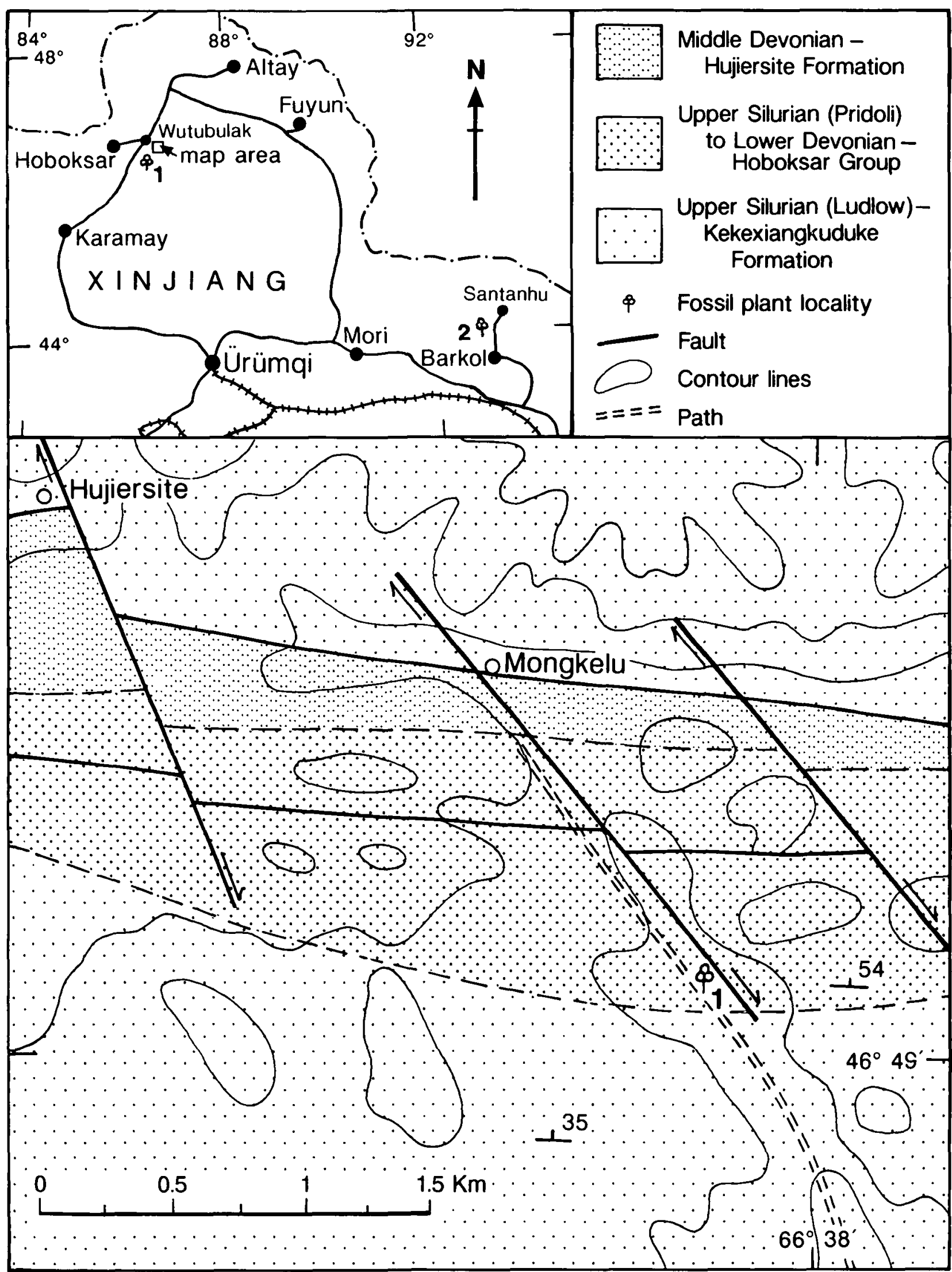

Figure 1. Location of the plant localities in north Xinjiang, China.

on the same side (Fig. 4a), with no indications of twisting, and are subtended at right angles to the wider 'main' axis. This is suggestive of a creeping rhizomatous system with erect fertile axes, yet the presence of examples with alternate branching, and again no twisting, points to a completely upright 
Table 1. Lithologies and fossils in the Wutubulake Formation (see also Fig. 2)

\begin{tabular}{|c|c|c|c|}
\hline $\begin{array}{l}\text { Bed No. } \\
\text { (Nos refer } \\
\text { to Fig. 2) }\end{array}$ & Lithology & Species List & $\begin{array}{l}\text { Thickness } \\
\text { (m) }\end{array}$ \\
\hline 5 & Grey-green tuffaceous sandstone & $\begin{array}{l}\text { Graptolites: Monograptus beatus Koren' }(=M . \\
\text { varithecatus Qiao), } M \text {. cf. lochkovensis Pribyl }(=M \text {. } \\
\text { exiguus Qiao) } \\
\text { Trilobite: Crotalocephalus cf. myops Koemer } \\
\text { Plants: ?Zosterophyllum sp. }\end{array}$ & 145 \\
\hline 4 & $\begin{array}{l}\text { Yellow-brown calcareous and tuffaceous fine-grained } \\
\text { sandstone intercalated with sandstone containing } \\
\text { pebbles and lenticular bioclastic limestone }\end{array}$ & $\begin{array}{l}\text { Graptolites: M. anerosus Koren' ( }=\text { M. junggarensis } \\
\text { Qiao) } \\
\text { Brachiopods: Leptostrophia rotunda Bulb, Ferganella sp., } \\
\text { Howellella sp. } \\
\text { Corals: Favosites sp., Syringaxon? sp. } \\
\text { Trilobites: Warbungella? aboronius Hsiang. } \\
\text { Bivalves: Goniophora (G) cf. trapezcidolis Kags; } \\
\text { Paracyclus cf. rugosa Goldf, Mytilus cf. beyrichi (Froch) } \\
\text { Chitinozoans: eg. Angochitina cf. echinata Eisenack } \\
\text { Plants: Salopella xinjiangensis, Junggaria spinosa Dou } \\
\text { (= Cooksonella sphaerica Senkevich) Sterile spiny axes }\end{array}$ & 38 \\
\hline 3 & $\begin{array}{l}\text { Grey-green tuffaceous fine to coarse-grained sandstone } \\
\text { intercalated with lenticular limestone }\end{array}$ & $\begin{array}{l}\text { Trilobites: Encrinurus sp. } \\
\text { Brachiopods: Leptostrophia rotunda Bulb. } \\
\text { Bivalves: Leptodesma sp., Cyrtodonta cf. simples Wilson }\end{array}$ & 43 \\
\hline 2 & Grey-green tuffaceous siltstone & & 48 \\
\hline 1 & $\begin{array}{l}\text { Grey-green calcareous fine-grained sandstone with } \\
\text { intercalations of sandstone containing pebbles } \\
\text { and conglomerate }\end{array}$ & & 86 \\
\hline
\end{tabular}

system. More fragmentary specimens with isotomously branching axes and terminal sporangia are possible detached lateral branch systems (Figs 4b, $5 \mathrm{~d})$, but the length of the longest fertile specimen collected $(6.5 \mathrm{~cm})$, with only isotomous branching and with two of the branches having attached sporangia, is perhaps more indicative of an erect isotomously branching main axial system in this case (Fig. 5e).

Most of the coalified axes appear parallel-sided with relatively smooth surfaces, but occasionally fine hair-like emergences (c. 50-100 $\mu \mathrm{m}$ diameter and $0.5 \mathrm{~mm}$ long) fringe axes. These are so faint that photography is difficult (e.g. Fig. 5f). Indeed it is quite remarkable that they are preserved at all in such a coarse matrix. In Figure $6 \mathrm{~g}$ they are directed towards the base of the fragment indicating that they were perhaps not rigid in life. We have not observed them on sporangia. A darker longitudinally orientated central strand is sometimes present on sterile axes, but characteristic tracheidal thickenings have not been demonstrated, hence the appellation rhyniophytoid.

All the sporangia possess a central circular area and wide border (Figs 5, 6). For dimensions see Table 2. The central area may be smooth and glassy (Fig. 61) or coarsely granular with irregular projections (Figs $5 \mathrm{a}-\mathrm{c})$. It is continuous with the subtending axis, making its height impossible to measure. Spores have neither been seen in, nor isolated from, the central region. The border may be of more or less uniform width (Fig. 6j) or lobed to varying degrees (Figs 6a-d, $j-k)$. When the former it terminates abruptly without tapering adjacent to the base of the central area and may even increase slightly in width. Very rarely and in small specimens, sporangial outline is more rounded. Throughout most of its length the border is in the form of a biconvex rim, fortuitous fracturing showing two coalified layers separated by matrix, whose thickness varies from sporangium to sporangium. The border appears convex (Fig. 6k) or concave (Fig. 6j) depending on the plane of fracture but is normally flattened and slightly wider near the truncated base. The two coalified layers of the border may be continuous at the periphery (Fig. 6e) over most of its length, but less commonly they overlap (Fig. 6b), or diverge, especially near the base of the sporangium. Thus in a transversely fractured sporangium the central region is a thick coaly layer and the border is represented by two diverging thinner lines. The central region sometimes extends as a narrow layer into the sediment between the two layers (Fig. 6c). Its maximum extent is $c .50 \%$ of the width of the border.

The border may be shallowly fluted or lobed with bevelled edge (Fig. 6k), or present a less regular, sometimes distorted appearance, with flatter margins lobed to varying extents. The two layers are again evident. In one developed example, part of the layer furthest away from the observer is parallel sided, part lobed, and the nearer one is more deeply lobed, but the lobes of the two layers are not coincident (Fig. 6b). In most of the examples on this small slab the lobing extends to approximately two-fifths of the border width. Deeper lobing where the tips appear attenuated and conical is shown in Figure $6 \mathrm{~g}$, i, where the lobes of the two layers are not superimposed and the border 


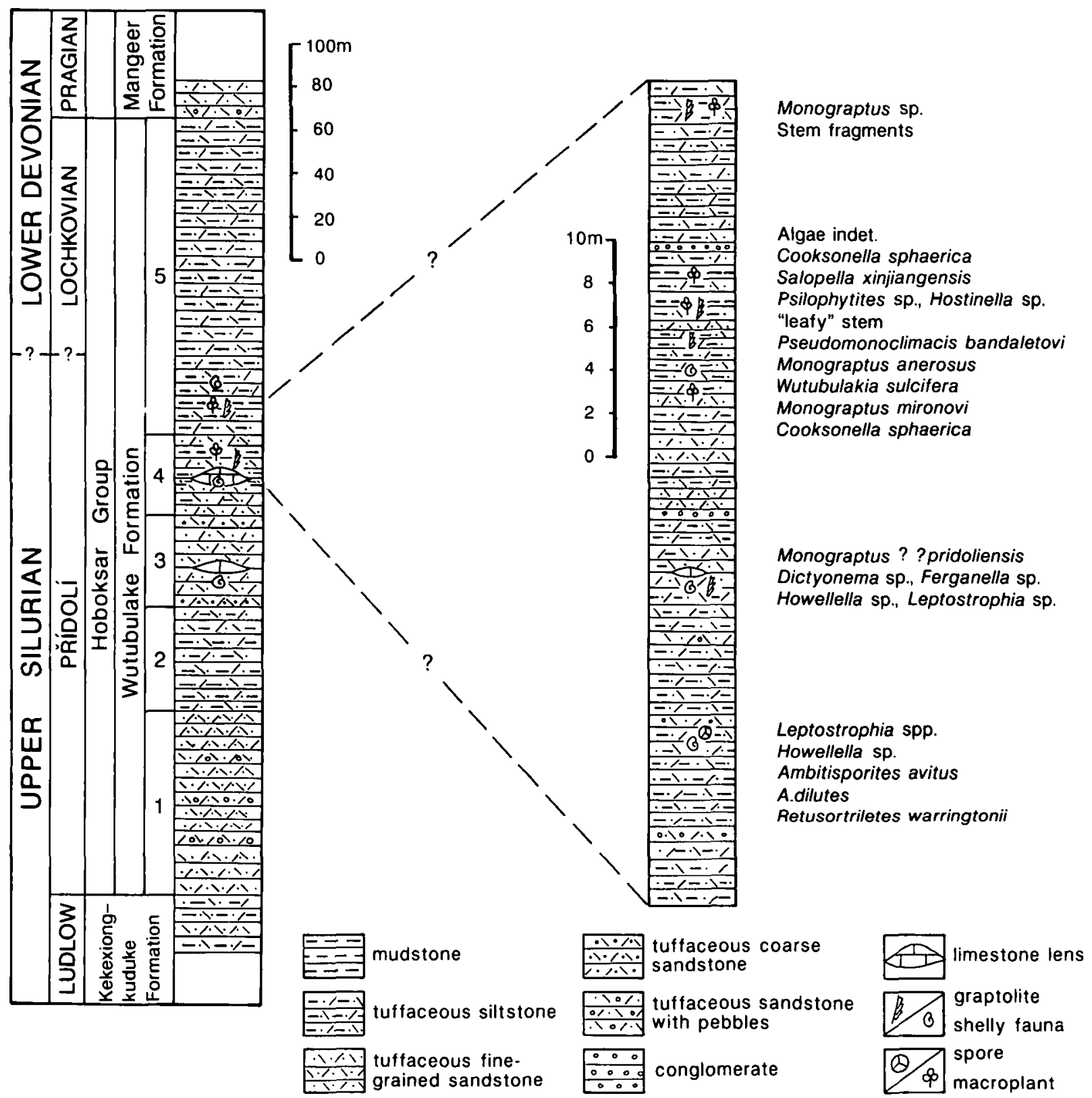

Figure 2. Stratigraphic and lithographic log of Upper Silurian and Lower Devonian exposures in north Xinjiang, China. 1-5: refer to Table 1 for description.

is flat. In such instances, the borders are not as well preserved as in the parallel-sided forms.

\section{5.a.2. Discussion}

Such variation in sporangium appearance immediately raises doubts as to the conspecificity of the specimens and, moreover, presents considerable problems in attempting to reconstruct the three-dimensional organization of the original sporangia: e.g. were they spheroidal or laterally compressed? In the commonest form, where the border is biconvex and its outline entire, comparison with Lower Devonian examples with borders suggests that the central region represents sporogenous tissue sandwiched between two layers of sporangium wall, while the margin is only sporangium wall. Peripherally fractured examples suggest that the sporangium split along the convex margin possibly into two equal values with margins of uniform thickness. This is quite different from compression of a Zosterophyllum sporangium (Edwards, 1969) where the more heavily coalified border results from a thickening of the sporangium wall (seen in permineralizations) immediately adjacent to the dehiscence line. The general organization may be similar to that in Uskiella spargens Shute \& Edwards, 1989 (=Cooksonia sp. Croft \& Lang, 1942) where the border is less heavily coalified than the rest of the sporangium and represents the thickness of the sporangium wall. However, it differs in that while in Uskiella the border is always flat, in Junggaria relief may be maintained by sedimentary infill. Further, the wall in the vicinity 
Table 2. Dimensions for specimens of Cooksonella sphaerica/Junggaria spinosa from China and Kazakhstan. All dimensions in millimetres

\begin{tabular}{|c|c|c|c|c|c|c|}
\hline \multicolumn{2}{|c|}{ Axis } & \multicolumn{5}{|c|}{ Sporangia } \\
\hline \multirow{2}{*}{$\begin{array}{l}\text { Max } \\
\text { width }\end{array}$} & \multirow{2}{*}{$\begin{array}{c}\text { Below } \\
\text { sporangium }\end{array}$} & \multirow[b]{2}{*}{ Height } & \multirow{2}{*}{$\begin{array}{l}\text { Width } \\
(\max )\end{array}$} & \multirow{2}{*}{$\begin{array}{l}\text { Central } \\
\text { region } \\
\text { width }\end{array}$} & \multicolumn{2}{|c|}{ Border } \\
\hline & & & & & Base & Top \\
\hline \multirow[t]{3}{*}{1.5} & \multirow[t]{3}{*}{$? 0.4$} & 3.8 & 4.0 & 2.6 & 1.5 & 0.7 \\
\hline & & $2.5^{*}$ & 4.0 & 2.2 & - & - \\
\hline & & 3.5 & 3.0 & - & - & 0.6 \\
\hline 1.1 & 0.9 & - & 5.0 & 2.5 & - & $<1.5$ \\
\hline 1.5 & 0.6 & 2.2 & 4.5 & 2.0 & 1.5 & - \\
\hline \multirow[t]{2}{*}{$<1.5$} & 1.0 & 3.0 & 4.5 & 2.5 & $<1.5$ & 1.0 \\
\hline & & 3.0 & 4.0 & 2.5 & - & 0.8 \\
\hline \multirow[t]{2}{*}{1.7} & 1.0 & 3.5 & 5.0 & 2.6 & 1.5 & 1.0 \\
\hline & & 3.0 & 4.5 & - & - & 1.0 \\
\hline \multirow[t]{2}{*}{1.4} & 0.5 & $2.3^{*}$ & 4.0 & 2.0 & 1.0 & - \\
\hline & & 3.5 & 4.0 & 2.0 & 1.2 & - \\
\hline 2.5 & - & 2.7 & 3.3 & 1.9 & 0.6 & - \\
\hline \multirow{2}{*}{1.2} & - & 3.5 & 4.5 & 1.7 & $0.75 \dagger$ & 1.5 \\
\hline & 1.0 & 3.5 & 4.0 & 2.0 & $0.7 \dagger$ & 2.0 \\
\hline- & 1.0 & - & 4.2 & 2.2 & 1.0 & 0.7 \\
\hline - & - & 2.5 & 3.5 & 1.8 & - & - \\
\hline - & 0.9 & 2.0 & 2.8 & - & - & - \\
\hline- & - & 3.0 & 3.5 & 2.2 & 0.8 & 0.6 \\
\hline- & - & $2.2^{*}$ & 3.8 & 2.0 & 1.0 & 0.8 \\
\hline \multicolumn{2}{|c|}{ Mean for this work } & 3.03 & 4.03 & 2.17 & 1.02 & 1.02 \\
\hline \multicolumn{2}{|c|}{ Dou's data } & $2.0-3.0$ & $4.0-5.0$ & $2.0-3.0$ & 1.5 & 0.5 \\
\hline \multirow{2}{*}{\multicolumn{2}{|c|}{$\begin{array}{l}\text { Senkevich Holotype } \\
1.85\end{array}$}} & 4.0 & 4.1 & - & - & - \\
\hline & & 3.2 & 3.6 & - & - & - \\
\hline
\end{tabular}

* Distorted.

† Markedly curved.

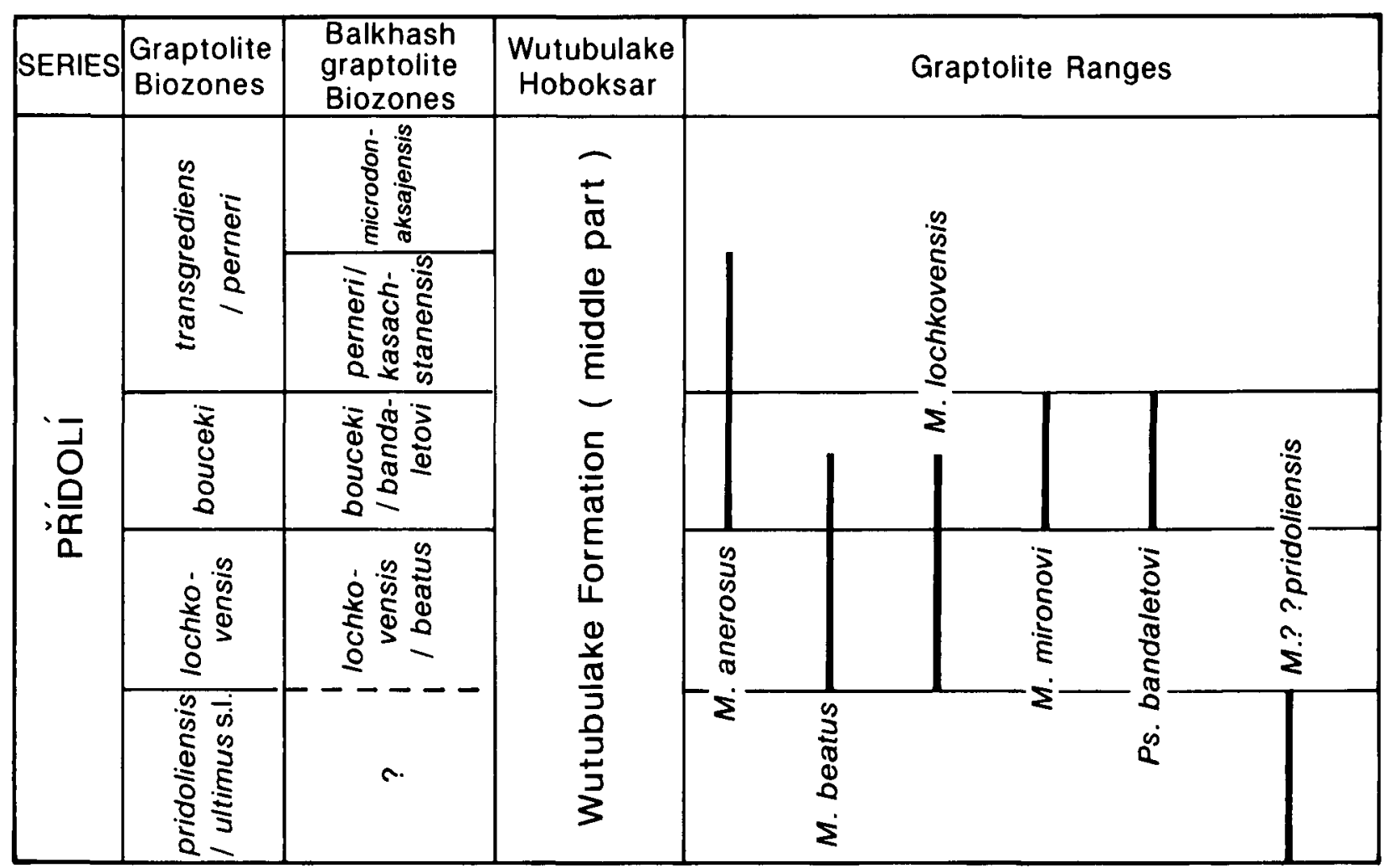

Figure 3. Graptolite zonation schemes and ranges in Xinjiang.

of the border must have been quite resilient and at least partially rigid to have kept its shape during fossilization. The distribution of sediment is intriguing, being confined to the border and absent from the central, presumed sporogenous, region. Is it possible that the bulk of inner wall tissue was thinwalled and readily degraded so that this region became filled with sediment which on compression was 

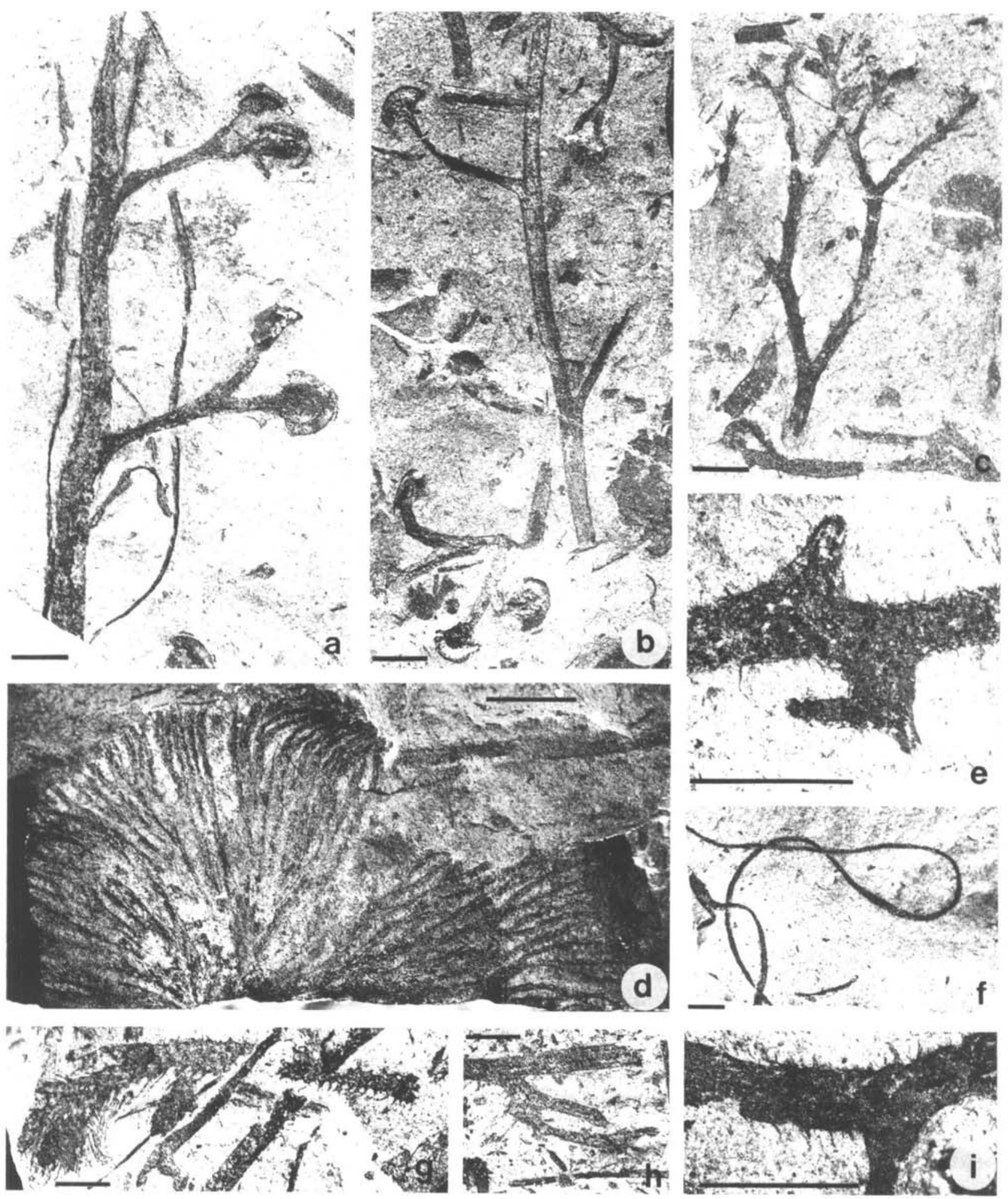

Figure 4. Coalified compressions from the Wutubulake Formation, north Xinjiang, China. Scale bars $3 \mathrm{~mm}$. (a) Cooksonella sphaerica Senkevich (= Junggaria spinosa Dou: Dou \& Sun, 1983, plate 3, fig. 5), with consecutive lateral branches on one side of the 'main' axis. Note also thong-like presumed alga. $730 \mathrm{H} \mathrm{1-44.} \mathrm{(b)} \mathrm{C.} \mathrm{sphaerica} \mathrm{with} \mathrm{pronounced} \mathrm{alternate} \mathrm{branching,} \mathrm{and}$ isotomously branching fertile fragment at bottom left. $730 \mathrm{H} 1-44 / 2$. (c) Branching system with short enations and slightly expanded tips. Specimen III/5. (d) Radiating branching axes of unknown affinity, those at top left moving down into matrix. $730 \mathrm{H} \mathrm{1-44.} \mathrm{(e)} \mathrm{Complex} \mathrm{branching} \mathrm{in} \mathrm{sterile,} \mathrm{hairy} \mathrm{axes.} \mathrm{Specimen} \mathrm{F.} \mathrm{(f)} \mathrm{Thong-like} \mathrm{fossils} \mathrm{of} \mathrm{probable} \mathrm{algal} \mathrm{affinities.}$ Specimen X. (g) 'Leafy' stem associated with smooth sterile axes. Specimen 3/8. (h) Complex branching in sterile axes. Note central strand in uppermost branch. Specimen III/4. (i) Sterile axis with spines. Specimen F. 

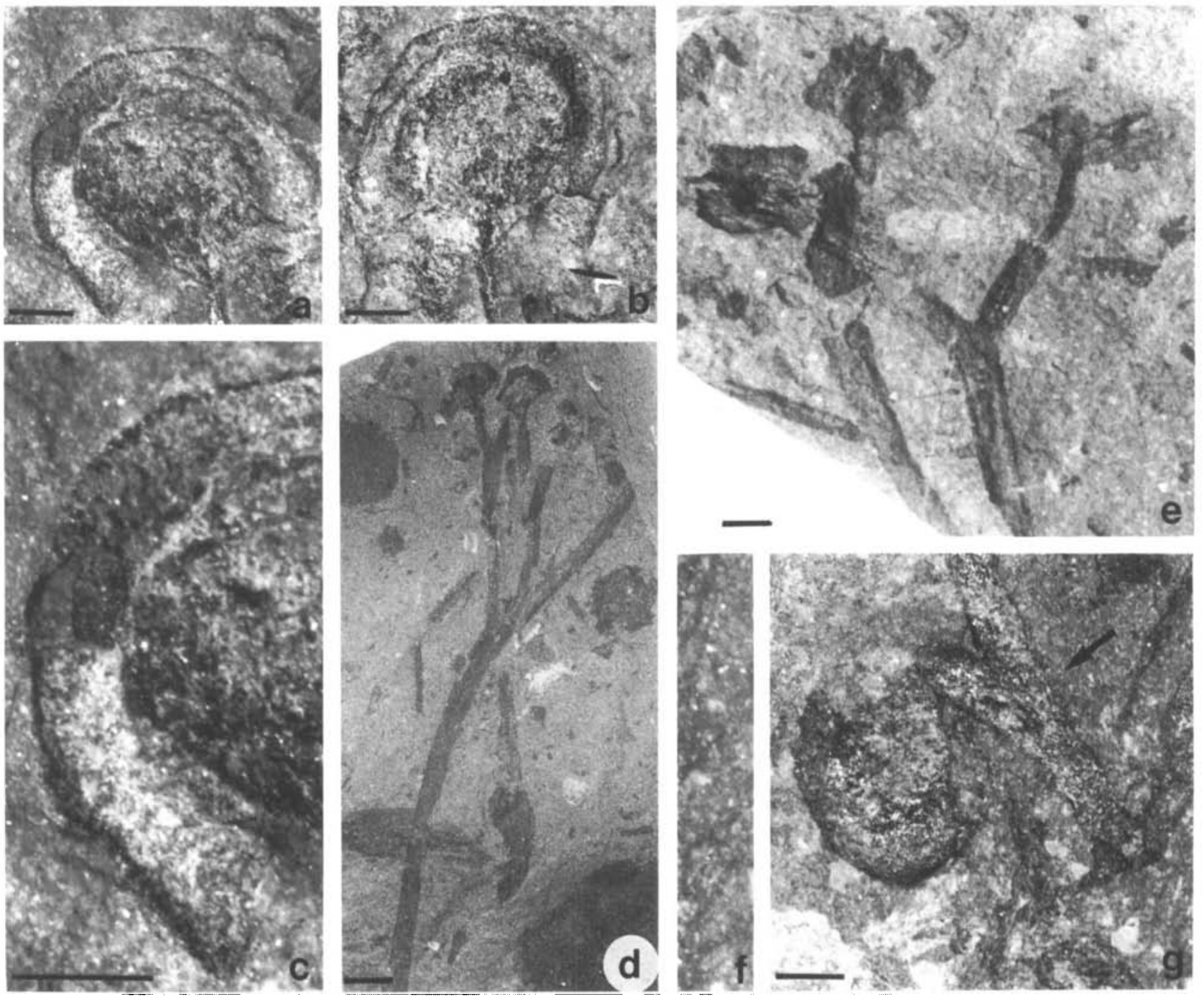

Figure 5. Cooksonella sphaerica Senkevich (Junggaria spinosa Dou), Wutubulake Formation, north Xinjiang, China. (a) and (b) part and counterpart of sporangium, with well-defined central region and border in which two layers are clearly visible. Note truncated base on the right in (b), with upper layer markedly wider than lower. Specimen II A/G, scale bars $1 \mathrm{~mm}$. (c) Part of (a) magnified to show details of border including a third layer extending from central area into sediment between the two layers of the border, scale bar $1 \mathrm{~mm}$. (d) Sporangia terminating isotomous branching. Specimen D4, scale bar $10 \mathrm{~mm}$. (e) Presumed erect dichotomously branching system with terminal sporangia. Specimen II/l, scale bar $10 \mathrm{~mm}$. (f) Barely distinguishable hairs from stem labelled with arrow in $(\mathrm{g})$. (g) Isotomously branching hairy axis with attached but displaced sporangium. $730 \mathrm{H} 1-44$, scale bar $1 \mathrm{~mm}$.

redistributed into the vicinity of the reinforced dehiscence area? Another possibility is that the wall was thin adjacent to the bulk of the sporogenous tissue, but then formed a ridge or crest almost completely encircling the sporangium, this structure in some way being concerned with dehiscence. Such a rim was postulated for the sporangia of Cooksonia hemisphaerica as reconstructed by Ananiev \& Stepanov (1969). Finally it is possible that the central area was a columella and that the 'border' represents the remains of a peripheral sporangial cavity protected from collapse by the presence of a thick walled region around the dehiscence line. This would explain why there is never any sediment in the central region even when the margin is degraded.

A further unusual feature of the Chinese sporangia, for which we have no convincing explanation, is the truncated rather than tapering ends of the sporangium border. The apparent small increase in width proximally can be accounted for by the straightening of the convex border. It seems that peripheral splitting started in this region and that this was the route by which sediment entered.

Deliberations such as these have led us to the tentative conclusion that all the sporangia belong to the same taxon and that variation may represent a developmental sequence in which sporangia with entire outlines are the youngest and those with deeply incised lobes, mature, even senescing, post-dehiscence forms, although we have postulated above that the borders represent relatively more resilient layers of the sporangium wall, particularly in the intact forms. In others, following dehiscence there is some evidence that approximately the outer third of the border was 

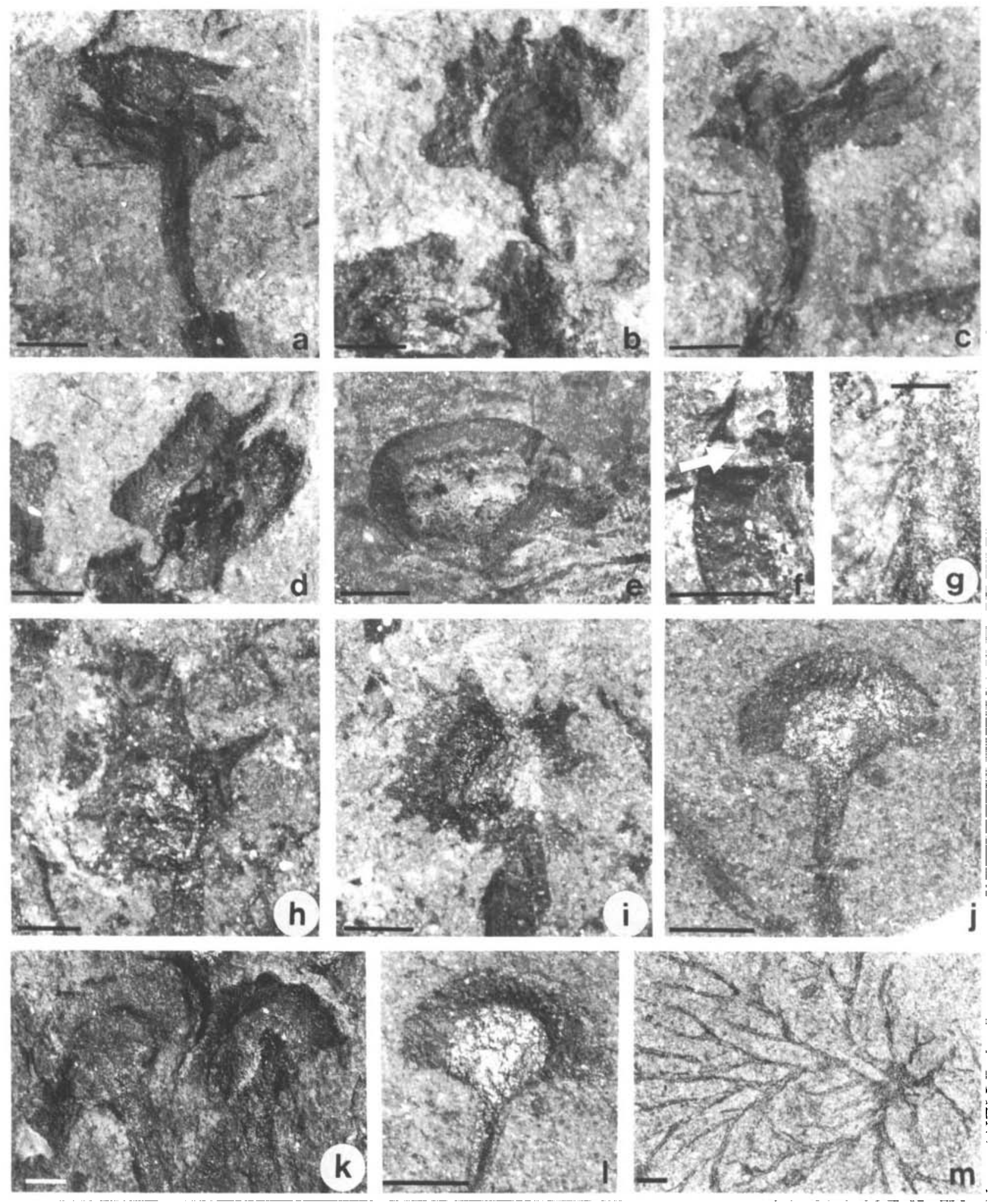

Figure 6. Coalified fossils from Xinjiang, northwest China. (a)-(d) Four sporangia from same branching system illustrating different appearances of the border. Arrows in (a) and (d) indicate branch point. Specimen D, scale bars $1 \mathrm{~mm}$. (e) Sporangium with elliptical outline (i.e. lacking truncated bases to border), border is markedly convex. Specimen D, scale bar $1 \mathrm{~mm}$. (f) Part of border showing sediment infill (arrowed) and coalified layer below, scale bar $1 \mathrm{~mm}$. (g) Reflexed hairs on axis, associated with sporangia. Specimen D, scale bar $0.5 \mathrm{~mm}$. (h) Sporangium with fragmentary border, with smooth and spiny outline. Specimen K, scale bar $1 \mathrm{~mm}$. (i) Sporangial border with jagged edge. Specimen B I/4, scale bar $1 \mathrm{~mm}$. (j) and (I) Sporangium with entire outline. Central region is smooth, border is concave. (l) photographed in unilateral light) $730 \mathrm{H} 1-44 / 2$, scale bar $1 \mathrm{~mm}$. (k) Two adjacent sporangia with pronounced relief. Specimen II/1, scale bar $2 \mathrm{~mm}$. (m) Indeterminate fossil where branching axes radiate from a possible holdfast, AEJ $308 / \mathrm{p}$, scale bar $1 \mathrm{~mm}$. 
less rigid (Fig. 6b, k) and may have degenerated first to give the shallowly lobed structures and eventually the deeply rayed forms, when the remains of the border become much flatter. We have no anatomical evidence to support this hypothesis, but the alternatives seem even less plausible! It is possible that the sporangium dehisced along a zigzag line, producing the alternating lobes, but the length of the lobes is always approximately equal to the width of the intact border and the mechanism is difficult to envisage.

It is also possible that the lobes reflect the structure of the mature sporangia, these belonging to a different species. Thus some sporangia would possess cone-like outgrowths (the rayed forms) in a row along the major circumference, and in others there would be short ridge-like outgrowths separated by furrows crossing the dehiscence line, looking rather like the sealed edges of two layers of thick pastry at the end of a pie. The apparent lack of coincidence of the lobes in the two layers is evidence against this.

The axes subtending sporangia provide little evidence for or against conspecificity. Hair or spine-like outgrowths are found on lobed and entire forms. As to branching pattern, sporangia with biconvex entire rims are found attached to the more complete pseudomonopodial system as well as to the isotomously branching representatives, while lobed and rayed forms usually terminate isotomous systems or unbranched axes. This may indicate two different kinds of growth habit, or that the pseudomonopodial branching systems are older and more robust. Since the number of specimens is small, and sorting and fragmentation must have occurred during transport, such generalizations have little value.

\section{5.a.3. Affinities}

These unique and somewhat bizarre sporangia thus defy our understanding. What is even more remarkable is their antiquity. Rhyniophytoid sporangia of comparable age, e.g. Salopella and Cooksonia display little or no sophistication in dehiscence (see e.g. Tims \& Chambers, 1984; Edwards \& Edwards, 1986; Edwards, Fanning \& Richardson, in press). The apical thickening in Steganotheca (Edwards, 1970) may have been an adaptation for spore liberation but may merely represent a flattened truncated apex. Sporangia with prominent spines have recently been described from the Pridoli of the Welsh Borderland at Perton Lane (Caia - Fanning, Edwards \& Richardson, 1990; Pertonella - Fanning, Edwards \& Richardson, 1991), but these are small, terminating narrow, predominantly isotomously branching axes and lack any indication of a border. Remarkably similar to Junggaria is the genus, Cooksonella, erected by Senkevich for plants with terminal sporangia recorded from sediments in neighbouring Kazakhstan once considered Gedinnian (Senkevich, 1975) but recently redated as Pridoli again on graptolitic evidence (Senkevich, 1986). Unfortunately, the illustrations are not sufficiently clear for satisfactory comparison, but Senkevich's description and dimensions fit the Chinese material (see Table 2). She described narrow axes, some with hairs, showing isotomous and pseudomonopodial branching with large terminal spherical or transversely elongate sporangia with thick twolayered wall and wide, flat rim, somewhat less heavily coalified than the rest of the sporangia. Senkevich's material possessed some cellular detail in the sporangial wall and she also recorded a central strand of narrow tracheids. She erected the new genus because the plants differed from Cooksonia in their pseudomonopodial branching, hairiness and the wide flat sporangial rim. Although one of the most important diagnostic characters of Junggaria, the truncated sporangial base, is not evident in descriptions of Cooksonella, and Senkevich did not record any rayed forms, we conclude that the two taxa are congeneric. Forms with rounded outline are also present in the Chinese material but are less conspicuous, less numerous, smaller and less photogenic than those with truncated bases. Truncated sporangial bases also distinguish most Junggarias from Lower Devonian Renalia (Gensel, 1976). The overall organization of the branching system is similar but simpler in the Chinese plant. Renalia also lacks hairs and spines. It is, however, possible that the organization of the cells adjacent to the dehiscence line in Junggaria is closer to that in Renalia than a Zosterophyllum. Comparison with other Emsian rhyniophytes or rhyniophytoids (Edwards \& Edwards, 1986) where sporangia also possess borders, e.g. Hsüa-China (Li Cheng-sen, 1982), Cooksonia crassiparietilis Kazakhstan (Yurina, 1969) and Sartilmania-Belgium (Fairon-Demaret, 1986) are hampered by insufficient anatomical data.

On balance, we believe that the Kazakhstan and Xinjiang specimens are congeneric, and hence the Chinese specimens are better named Cooksonella sphaerica. However, that genus was first used by Nagy (1965) for a leiosphaerid (C. circulairs) from the Neogene of southern Hungary. A new genus is thus required for the Silurian plants, and as recommended by the International Code of Botanical Nomenclature, this should not be Junggaria. Adequate diagnosis of this new genus demands a re-examination of the original material, and until this is possible we prefer to leave the plants unnamed.

\section{5.b. Salopella xinjiangensis Dou}

The description and diagnosis was based on a single specimen (Dou \& Sun, 1983, pl. 189, fig. 8), which was not available for reinvestigation. The original illustration shows narrow flexuous isotomizing axes ( 0.3 to $1.0 \mathrm{~mm}$ wide) and what was described as a single tongue-shaped sporangium, $3.5 \mathrm{~mm}$ long with 
rounded apex and maximum width $(1.5 \mathrm{~mm})$ at its base, where it is more sharply delimited from the subtending axis than other Salopella species. Spores have not been isolated. An asymmetrically positioned longitudinal ridge is a further distinguishing feature, and because of this and the fact that the axis is said to increase in width below the sporangium, the specimen was assigned to a new species of Salopella. However, it is possible that these two features result from the partial superpositioning of two apical sporangia borne close to a dichotomy. The sporangium is smaller than that in the three described species, $S$. allenii Edwards and Richardson (1974), S. australis and S. caespitosa Tims and Chambers (1984), but it is closer in size but not in shape to some unnamed forms from the Gedinnian of the Welsh Borderland (Edwards \& Fanning, 1985; Fanning, Edwards \& Richardson, 1992), and to Eorhynia (Ishchenko, 1975) from the Pridoli of Podolia.

\section{5.c. Sterile axes (Figs $4 \mathrm{e}, \mathrm{h}, \mathrm{i}$ )}

These show a variety of branching patterns, and surprisingly, few can be assigned to Hostinella, because they lack the characteristic symmetry both in axis diameter following branching and in distances between successive branch points in daughter systems. The longest fragment found measured $45 \mathrm{~mm}$. Some axes show both isotomous and pseudomonopodial branching, while in others there is isotomy accompanied by overtopping. Enations in the form of hairs and small spines (Fig. $4 \mathrm{e}, \mathrm{i}$ ) are common and such axes probably belong to 'Cooksonella/Junggaria', although when isolated and sterile are better named Psilophytites sp. except that this genus was based on vascularized axes. Many of the axes appear flexuous, some show longitudinal ribbing. Fragments with $\mathrm{H}$ - and $\mathrm{K}$ - and more complex clustered branching (Fig. $4 \mathrm{e}, \mathrm{h}$ ) are not uncommon, and led Dou \& Sun (1983, pl. 189, figs 6 and 7) to record Zosterophyllum in the assemblage. However, some of the pieces have punctate surfaces and irregular margins suggestive of hairs and spines and thus may belong to 'Cooksonella/Junggaria'. They do not belong to Zosterophyllum; it is unwise to attribute even smooth axes to that genus on the basis of branching patterns as our knowledge of the overall organization of plants of this age is so limited.

\section{5.d. Incertae sedis}

\section{5.d.I. Specimen illustated in Figure $4 \mathrm{c}$}

A single specimen consists of a coalified isotomously branching axial system, $2.2 \mathrm{~cm}$ long, with occasional lateral enations and terminating in clusters of spinelike emergences and slightly expanded truncated structures (Fig. 4c). Longitudinal ridging and striations are present on these wedge-shaped extremities. Proximally there is a decrease in diameter after each division, the widest axis being $c .1 .1 \mathrm{~mm}$. The proximal enations are widely scattered, inserted at $45^{\circ}$, and directed distally. They are parallel-sided, c. $0.1 \mathrm{~mm}$ wide and up to almost $1 \mathrm{~mm}$ long and usually end abruptly; this may be related to lack of preservation of more delicate tapering tips in such a coarse sediment. Branching is less regular in the terminal regions and the ends of the axes occur at different levels in the sediment.

Spinous axes of this kind, if vascular, would be assigned to Psilophytites, but the apices are more reminiscent of those in presumed algae, such as Powysia bassettii (Silurian: mid-Wales). Powysia itself is more extensive, less regularly branched, of tubular construction and possesses a well defined holdfast.

Uncertainty arises as to the systematic position of Powysia because similar morphology is found in some animal fossils (e.g. dendroid graptolites; Bull, 1987). However, as in Powysia, there is no compelling evidence for thecae in the Chinese material making an algal or even tracheophyte affinity probable, but more precise relationships are impossible to establish.

\section{5.d.2. Specimens illustrated in Figures $4 g$ and 7}

The terminal fragment, about $2.5 \mathrm{~cm}$ long, is covered by crowded linear emergences, at least $3.0 \mathrm{~mm}$ in length, but probably longer as they were difficult to trace from base to apex because of overlapping and incomplete tips. Where parallel-side (Fig. 7a) the emergences are $c .0 .2 \mathrm{~mm}$ in diameter and widen to $0.43 \mathrm{~mm}$ at the point of attachment. This is most clearly seen at the base of the specimen where most of the emergences have broken off. In this region the surface of the axis shows a marked relief produced by the enlarged bases of the emergences (Fig. 7), but there is no regular phyllotaxis. There being no indication of longitudinal trace or tracheids in the emergences, there is no unequivocal evidence for microphylls and hence for a lycophyte affinity of the fossil, but it must be admitted that the outgrowths are so narrow that detection of such a trace would be very difficult. There is a superficial lycophyte resemblance based on the leafy appearance and nature of the axis surface. In the former it resembles a small Baragwanathia; in the latter a fragment of Drepanophycus spinaeformis with closely spaced leaves, although the shape of the microphylls in Drepanophycus is different. Similar fossils from Pridoli sediments in Podolia, again lacking anatomy and with less distinct, very crowded, hair-like emergences were named Lycopodolica tsegelnjucki. It is also possible that the fragment is part of a spinous zosterophyll, such as Sawdonia ornata, but it lacks circinate vernation. Indeed, Ishchenko (1975) named a small fragment resembling that in Figure $4 \mathrm{~g}$ and from the Podolian Pridoli, as Protosawdonia prima. Considering algae, 

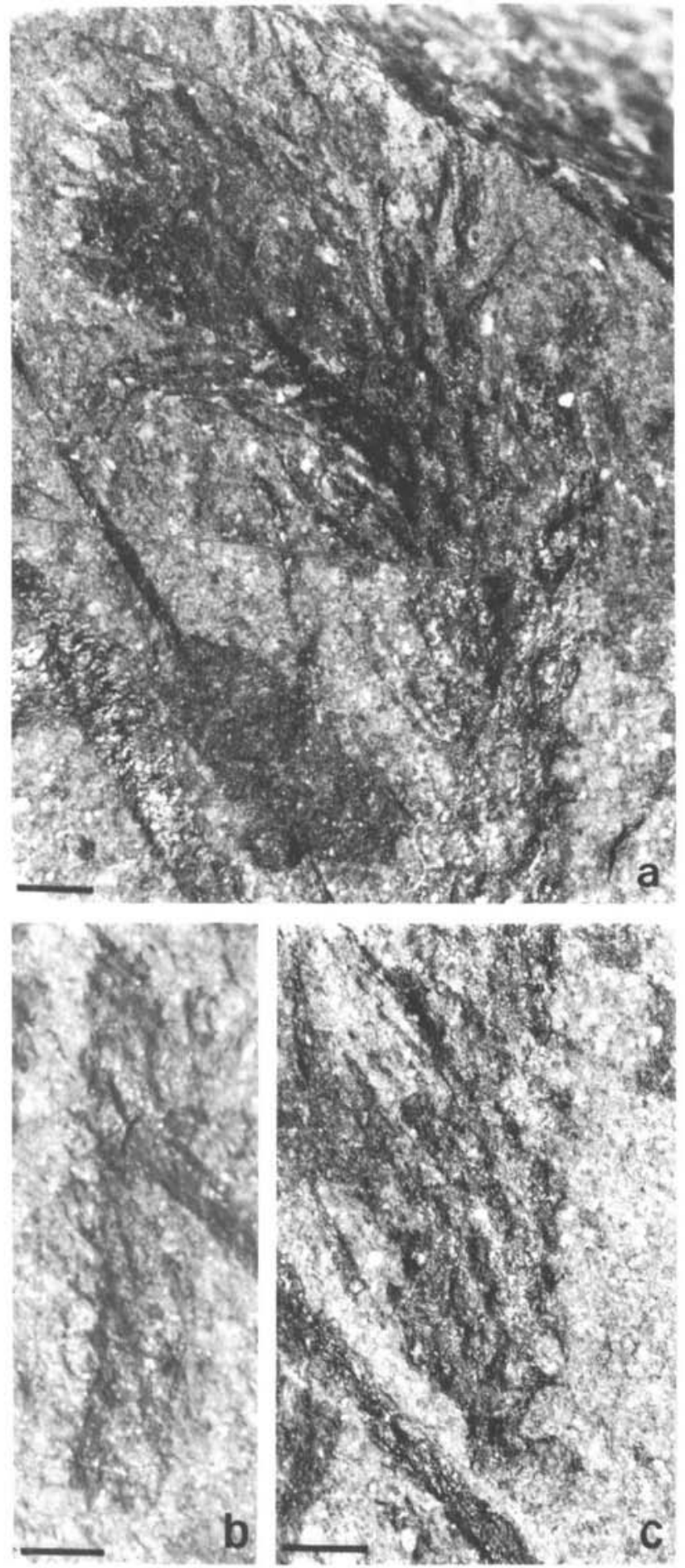

Figure 7. 'Leafy' axis from Xinjiang, north China. Specimen $3 / 8$, scale bars $1 \mathrm{~mm}$. (a) Distal region showing needle-like proximal 'leaves' and expanded 'leaf' bases. (b) Part of specimen with bases of 'leaves' in profile and as swellings on the stem surface. (c) Part of stem photographed under unilateral illumination to show surface topography.

there is some superficial similarity with the terminal part of a Chaetocladus, or putative dasycladacean, but in the absence of any evidence for articulation such an affinity is discounted. There are also superficial similarities to the gametophyte of a moss. We therefore leave the specimen unnamed and of uncertain taxonomic position.

\section{5.d.3. Specimens illustrated in Figures $4 d$ and $6 \mathrm{~m}$}

The specimens illustrated in Figures $4 \mathrm{~d}$ and $6 \mathrm{~m}$ are typical of those originally described by Dou (in Dou \& Sun, 1983, pl. 189, fig. 5) as a new species of Sciadophyton, S. pristinum. Very narrow dichotomously branching axes (Fig. $6 \mathrm{~m}$ ) radiate from a small central coalified area, set in a depression (or an elevation in other specimens). This probably represents a holdfast. Such fossils are circular or oval in outline and may exhibit marked curvature towards the edge (Fig. 4d). The axes themselves have irregular margins, except in one case where they are much wider impressions and it seems likely that here staining may have extended from the original organism. There are no indications of central strands, and because of this, the narrowness of the axes and the branching pattern, such fossils should not be placed in Sciadophyton (recently interpreted as a gamotophyte (see e.g. Schweitzer, 1983)). Again whether they are plants or animals is conjectural. If the former, an algal affinity seems likely, and the genus Buthotrephis (?Phaeophyceae in Johnson \& Konishi, 1959) a possibility. Schweitzer (1983) recently illustrated a reconstruction of Buthotrephis retski from the Emsian of the Rhineland, with similar symmetry and branching to the Chinese specimens, although precise placement within the algae is impossible on the morphology of a sterile thallus. If animal as seems more likely they are best compared with dendroid graptolites as, for example, illustrated in Boucek (1957) (D. K. Loydell, pers. comm. 1991).

\section{5.d.4. Specimens illustrated in Figures $4 a, f$}

An algal affinity also seems most likely for the long, parallel sides, narrow and rarely branched thread-like axes.

\section{Environment of deposition}

As is the case for all other Silurian records the sediments in which the Chinese plants are preserved are marine, and thus give no clues as to the habitats of the land plants. Their relatively good state of preservation and large size indicate that the plants were transported a short distance, probably as rafts with drifting remains of indigenous plants before sinking and burial. The sediments of the Wutubulake Formation include tuffaceous sands, with carbonate lenses and thin layers of silts and muds, and contain shelly and graptolitic faunas. Interpretations of depositional environments range from shallow shelf (Rong \& Chen, 1992) to low energy, dysaerobic trough settings (?deep) with distal turbidites. This suggests to Chinese workers oscillating sea levels due to tectonic activity in Pridoli times, a scenario consistent with the proposed proximity of the area to plate boundaries (Fig. 8). Alternatively, the diversity 


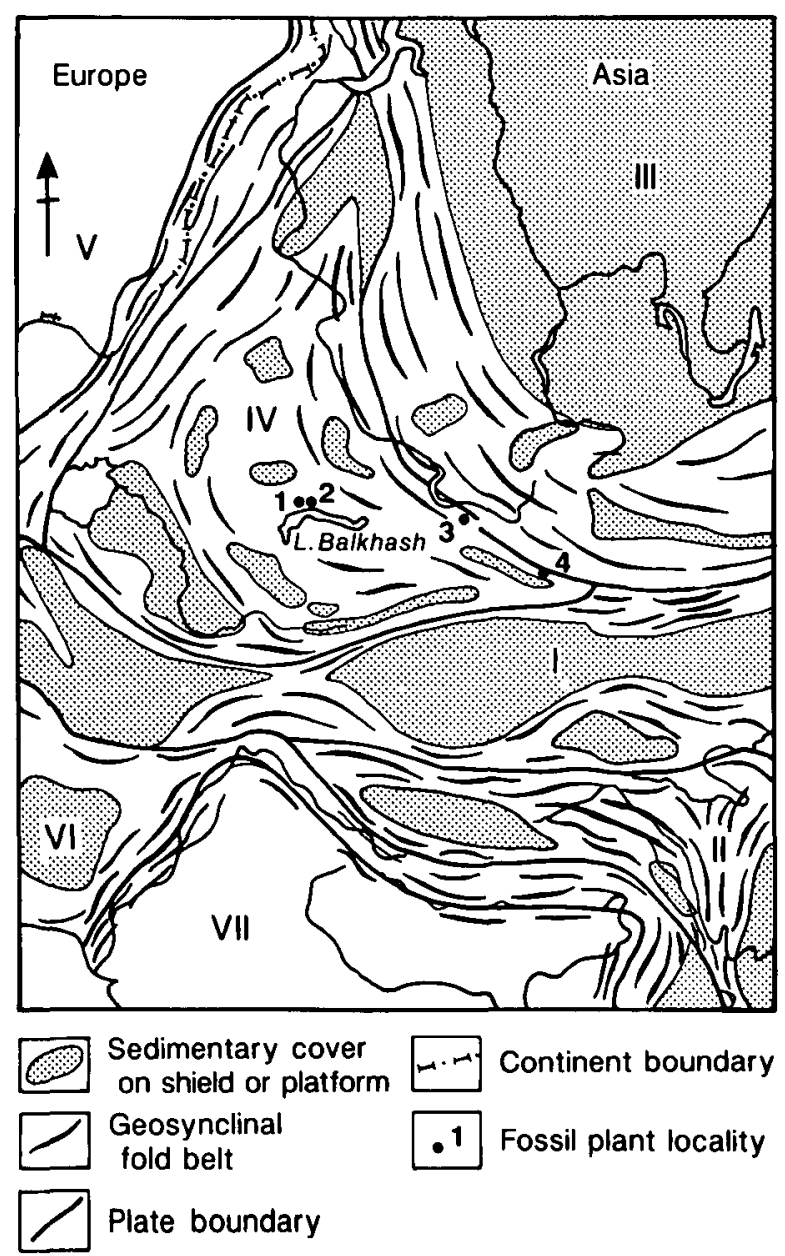

Figure 8. Map showing distribution of palaeoplates in Asia (after Li et al. 1982). Localities 1 and 2 are in Kazakhstan, 3 and 4 in China.

of faunas and facies might indicate offshore transport of sediments during storm disturbance of shelf environments.

\section{Tectonic setting and palaeogeography}

The palaeogeographic position of the plant-bearing localities is debatable, as the area was located at or near the folded basinal belt or plate suture line between the Siberian and Kazakhstan plates. Thus, for example, Mu et al. (1982) thought that the Junggar Basin was part of the North Junggar-Xingan Region, but it was later placed in the northernmost or JunggarHinggan Region (Mu et al. 1986), while Lin et al. (1983) located it in the Tienshan Nei Monggol (Inner Mongolia) Region. On the palaeogeographic reconstructions in McKerrow \& Scotese (1990) the locality was on the margin of the Siberian plate (see e.g. Edwards, 1990). However, it was even then abundantly evident from fauna, flora and lithofacies that there was a close relationship with Kazakhstan in Silurian times and thus the western part of the Junggar basin is better attached to the Kazakhstan palaeocontinent. Although earlier in the Palaeozoic Kazakhstan com- prised an amalgamation of exotic terranes and island arcs (Li \& Wang, 1983, Li et al. 1982; Scotese \& McKerrow, 1990), by late Ordovician times it was probably a discrete continent (Fig. 9; Scotese \& McKerrow, 1991). Cocks \& Scotese (1991) state that 'the dominance of tropical limestones and numerous corals at many horizons and localities testify that the continent must have lain not far from the Silurian palaeoequator' (p. 117) (see Wilde, Berry \& QuinbyHut, 1991), although its position relative to neighbouring palaeocontinents is still conjectural.

\section{Distribution and composition of Pridoli assemblages}

Of the ten Pridoli assemblages listed by Edwards (1990), those in southern Britain (3), the United States (1) and Podolia (1) were preserved on the developing palaeocontinent Laurussia, those from Libya (1) and Czechoslovakia (1) on northern Gondwana, and the Chinese (1) and Kazakhstanian (2) on Kazakhstania (Fig. 9). Gondwana and Laurussian occurrences (Table 3) are dominated by the genus Cooksonia with the most diverse recorded from South Wales (Freshwater East, Dyfed: Edwards, 1979) the Welsh Borderland (Perton Lane, Hereford: Lang, 1937; Fanning, Edwards \& Richardson, 1990, 1991) and Podolia (Ishchenko, 1975). Extensive collections from Perton Lane have yielded a wide range of rhyniophytoids including three or four species of Cooksonia, elongate sporangia of Salopella-type, some of which contain dyads, and two kinds of sporangia with prominent spines. Although axes with small spines have been described from Perton Lane, 'leafy' examples with resemblances to lycophyte shoots have not been discovered. These are perhaps the most intriguing fossils in the Podolian, Kazakhstan and Chinese localities (Table 3), and a single specimen has also been recorded from Argentina (Cuerda et al. 1987), where the age of the deposit is equivocal (? Devonian). As yet there is neither anatomical nor reproductive evidence to support affinity with the lycophytes, and their identification as Baragwanathia or even Lycopodolica (Ishchenko, 1975) is premature. It is perhaps of some significance that these records are all in marine strata and may be of algae. This may seem to be a somewhat weak argument as all Silurian plant records are from marine rocks, but similar remains are not recorded from younger fluvial rocks with rhyniophytoids. Alternatively, this may reflect regional differences as the 'leafy' fossils are not recorded in older marine rocks in the same area.

In the Kazakhstanian assemblages, the sporangia of Cooksonella are larger than coeval rhyniophytoids elsewhere and the distinctive marginal feature is unique. Diameter of axes is also greater than in Laurussia and branching patterns are more complex and varied. $\mathrm{K}$ - and $\mathrm{H}$-branching partially characterizes 


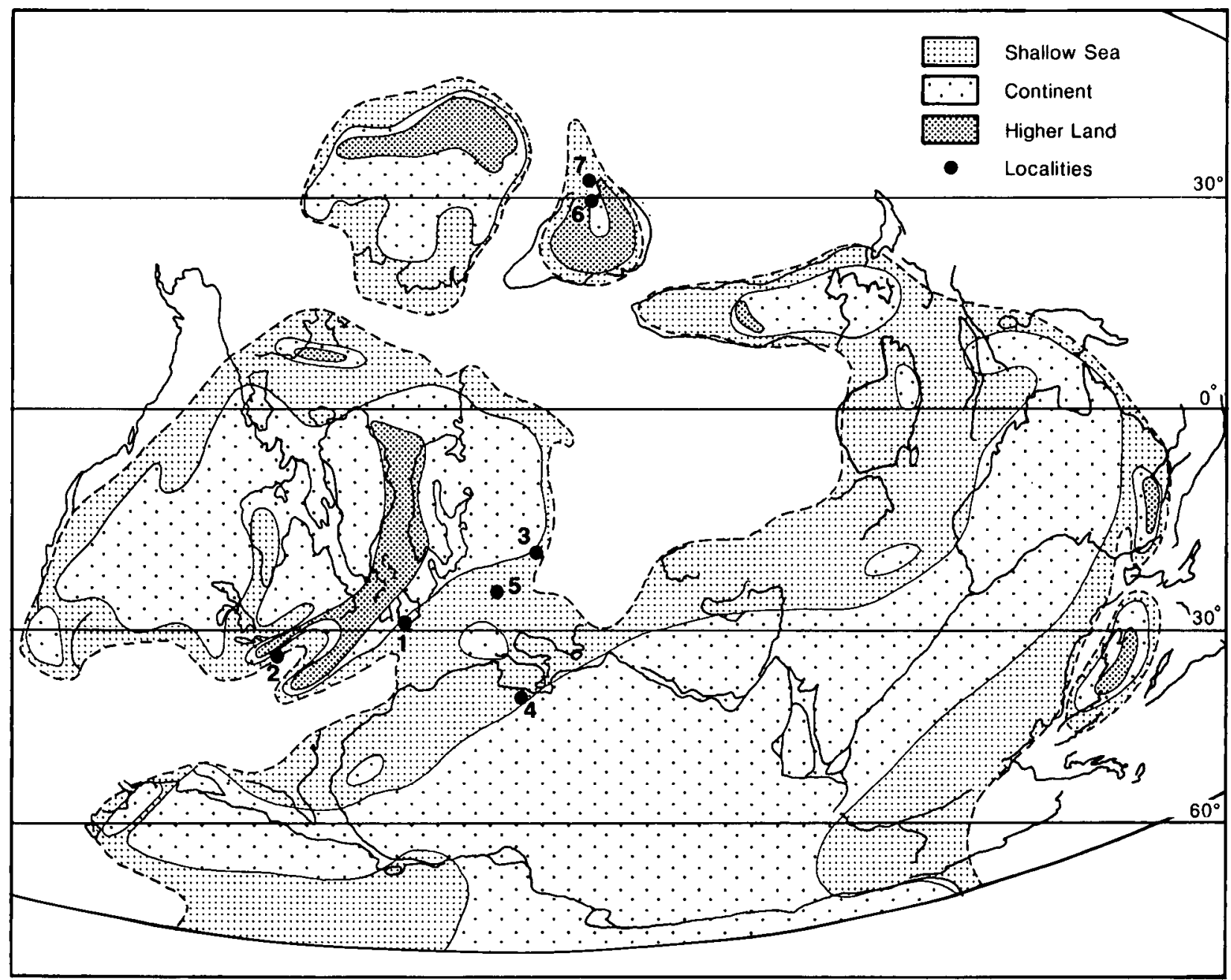

Figure 9. Silurian localities for land plants plotted on the earliest Gedinnian land/sea reconstruction produced by McKerrow \& Scotese (1990) and redrawn from Cocks \& Scotese (1991). Outlines of some present day continents have been omitted for clarity.

Table 3. Distribution of Pridoli taxa

\begin{tabular}{|c|c|c|c|c|c|c|c|c|c|}
\hline & \multicolumn{3}{|c|}{ UK } & \multirow[b]{2}{*}{$\begin{array}{c}\text { USA } \\
2\end{array}$} & \multirow[b]{2}{*}{$\begin{array}{c}\text { Podolia } \\
3\end{array}$} & \multirow[b]{2}{*}{$\begin{array}{c}\text { Libya } \\
4\end{array}$} & \multirow[b]{2}{*}{$\begin{array}{c}\mathrm{Cz} \\
5\end{array}$} & \multirow[b]{2}{*}{$\begin{array}{c}K \\
6\end{array}$} & \multirow[b]{2}{*}{$\begin{array}{l}\mathrm{C} \\
7\end{array}$} \\
\hline & $\begin{array}{c}\text { FWE } \\
1\end{array}$ & $\begin{array}{c}\mathrm{PL} \\
1\end{array}$ & $\begin{array}{c}\mathrm{CH} \\
1\end{array}$ & & & & & & \\
\hline Cooksonia & + & + & + & + & + & + & + & - & - \\
\hline Salopella & + & + & - & - & + & - & - & - & $?$ \\
\hline Psilophytites & + & + & - & - & - & - & - & - & + \\
\hline Caia & - & + & - & - & - & - & - & - & - \\
\hline Pertonella & - & + & - & - & - & - & - & - & - \\
\hline "lycophyte" & - & - & - & - & + & - & - & + & + \\
\hline Tortilicaulis & + & + & - & - & - & - & - & - & - \\
\hline Steganotheca & - & - & + & - & - & - & - & - & - \\
\hline 'Cooksonella' & - & - & - & - & - & - & - & + & + \\
\hline Zosterophyllum & 一 & - & - & - & + & - & - & $?$ & - \\
\hline Jugumella & - & - & - & - & - & - & - & + & - \\
\hline
\end{tabular}

FWE $=$ Freshwater East, Edwards, 1979; PL = Perton Lane, Lang, 1937; Fanning et al $.1991 ; \mathrm{CH}=$ Capel Horeb, Wales, Edwards, $1970 ;$ Edwards and Rogerson, 1979; USA = Banks, 1973; Podolia = Ishchenko, 1975; Libyan $=$ Daber, 1971. Cz = Czechoslovakia, Obrhel, 1962; K = Kazakhstan, Senkevich, 1975, 1986; C = China, herein. Numbers refer to localities on Figure 9.

Early Devonian Zosterophyllum in Laurussia, but in China is probably present in Cooksonella (Junggaria). It should therefore not be taken in isolation as evidence for the existence of Zosterophyllum. As yet strobili of Zosterophyllum have not been recorded in the Silurian of China, but problematical remains collected in Kazakhstan by N. Petrosyan (pers. comm. 1983) require further investigation. 
The Chinese and Kazakhstanian assemblages were thus distinctive but with levels of organization only marginally different from those elsewhere. Whether or not such differences indicate a phytochorion distinct from Laurussia and north Gondwana in Pridoli times remains conjectual. Perhaps less equivocal, but not yet actually demonstrated, is the existence of an Australian phytochorion in the latest Silurian as the Baragwanathia flora is recorded in the Ludlow, and persists into the Lower Devonian.

\section{References}

Ananiev, A. R. \& Stepanov, S. A. 1969. The first discovery of the Psilophyton flora in the Lower Devonian Salairski Ridge Locality (West Siberia). Records of Tomsk State Kujbyshev University. The works of the Tomsk order of the Worker's Red Banner of the State University named after Kujbyshev 203, 13-28.

Banks, H. P. 1973. Occurrence of Cooksonia, the oldest vascular land plant macrofossil, in the Upper Silurian of New York State. Journal of the Indian Botanical Society Golden Jubilee 50A, 227-35.

BouCEK, B. 1957. The dendroid graptolites of the Silurian of Bohemia. Rozpravy ustredniho Ustavu Geologickeho, Praha 23, 1-294.

Bull, E. E. 1987. Upper Llandovery dendroid graptolites from the Pentland Hills, Scotland. Palaeontology 30, $117-40$.

CAI, C. Y. \& Ll, X. X. (In press.) A review on the recent studies in Silurian and Devonian macrofossil plants in China. Palaeontologica Cathaysiana No. 6.

Cocks, L. R. M. \& SCOTESE, C. R. 1991. The global biogeography of the Silurian Period. In The Murchison Symposium: proceedings of an international conference on the Silurian System. (eds M. G. Bassett, P. D. Lane and D. Edwards), pp. 109-122. Special Papers in Palaeontology no. 44.

Croft, W. N. \& Lang, W. H. 1942. The Lower Devonian flora of the Senni Beds of Monmouthshire and Breconshire. Philosophical Transactions of the Royal Society of London, B231, 131-63.

Cuerda, A., Cingolani, C., Arrondo, O., Morel, E. \& GANUZA, D. 1987. Primer registro de plantas vasculares en la Formacion Villavicencio, Precordillera de Mendoza, Argentina. IV Congresso Lantinoamericano de Paleontologia, Bolivia (1987) 1, 179-83.

DABER, R. 1971. Cooksonia: one of the most ancient psilophytes - widely distributed, but rare. Botanique (Nagpur) 2, 35-9.

Dou, Y.W. \& SuN, Z. H. 1983. Devonian Plants. In Palaeontological Atlas of Xinjiang, Vol. II. Late Palaeozoic Section. Geological Publishing House, Beijing (in Chinese).

Dou, Y.W. \& Sun, Z. H. 1985. On the Late Palaeozoic plants in Northern Xinjiang. Acta Geologica Sinica 59, 1-10 (in Chinese with English summary).

EDwards, D. 1969. Zosterophyllum from the Lower Old Red Sandstone of South Wales. New Phytologist 68, 923-31.

Edwards, D. 1970. Fertile Rhyniophytina from the Lower Devonian of Britain. Palaeontology 13, 451-61.

Edwards, D. 1979. A late Silurian flora from the Old Red Sandstone of south-west Dyfed. Palaeontology 22, 23-52.
Edwards, D. 1990. Constraints on Silurian and Early Devonian phytogeographic analysis based on megafossils. In Palaeozoic Palaeogeography and Biogeography (eds W. S. McKerrow and C. R. Scotese), pp. 233-42. Geological Society Memoir no. 12.

Edwards, D. \& EDwards, D. S. 1986. A reconsideration of the Rhyniophytina. In Systematic and taxonomic approaches in palaeobotany (eds R. A. Spricer and B. A. Thomas). Systematics Association Special Volume no. 31. Oxford: Clarendon Press.

Edwards, D. \& Fanning, U. 1985. Evolution and environment in the late Silurian-early Devonian: the rise of the pteridophytes. Philosophical Transactions of the Royal Society of London, B 309, 147-65.

Edwards, D. \& Richardson, J. B. 1974. Lower Devonian (Dittonian) plants from the Wesh Borderland. Palaeontology 17, 311-24.

Edwards, D. \& Rogerson, E. C. W. 1979. New records of fertile Rhyniophytina from the late Silurian of Wales. Geological Magazine 116, 93-8.

Edwards, D., Fanning, U. \& Richardson, H. B. (In press.) In situ spores in early land plants from Wales and the Welsh Borderland: a review. Proceedings of the Geologists Association.

FaIRON-DEmareT, M. 1986. Les plantes emsiennes du Sart Tilman (Belgique). II Sartilmania jabachensis (Kräusel et Weyland) comb. nov. Review of Palaeobotany and Palynology 47, 225-39.

Fanning, U., Edwards, D. \& Richardson, J. B. 1990. Further evidence for diversity in late Silurian land vegetation. Journal of the Geological Society 147, 725-28.

Fanning, U., Edwards, D. \& Richardson, J. B. 1991. A new rhyniophytoid from the late Silurian of the Welsh Borderland. Neues Jahrbuch für Geologie und Paläontologie 183, 37-47.

FanNing, U., Edwards, D. \& Richardson, J. B. 1992. A diverse assemblage of early land plants from the Lower Devonian of the Welsh Borderland. Botanical Journal of the Linnean Society 109, 161-88.

GenG, L. Y. \& LI, Z. P. 1984. Chitinozoans from the Yulongsi Formation. Acta Micropalaeontologica Sinica 1, 100-4. (in Chinese with English summary).

Gensel, P. G. 1976. Renalia hueberi, a new plant from the Lower Devonian of Gaspé. Review of Palaeobotany and Palynology 22, 19-37.

He, S. Y. 1988. The Silurian System. In Palaeontogeography of China (ed. H. F. Yin), pp. 111-33 (in Chinese).

Hou, H. F., Xiang, L. W., Lal, C. G. \& Lin, B. Y. 1979. Advances in the Palaeozoic stratigraphy of TianshanXingan region. Acta Stratigraphica Sinica 3, 175-87 (in Chinese).

IshCHenko, T. A. 1975. The Late Silurian flora of Podolia. 1-180. Naukova Dumka, Kiev.

Johnson, J. H. \& Konishi, K. 1959. Studies of Silurian (Gotlandian) algae. Quarterly of the Colorado School of Mines 5, 1-173.

Koren, A. E. 1983. New late Silurian monograptids from Kazakhstan. Palaeontology 26, 407-34.

LANG, W. H. 1937. On the plant remains from the Downtonian of England and Wales. Philosophical Transactions of the Royal Society B227, 245-91.

LeE, H. H. \& TsaI, C. Y. [= Li, X. X. \& Cai, C. Y.]. 1978. III Devonian floras of China. In Papers for the International Symposium on the Devonian System, pp. 1-8. Nanking 
Institute of Geology \& Palaeontology. Academia Sinica.

Li Cheng-Sen. 1982. Hsüa robusta, a new land plant from the Lower Devonian of Yunnan, China. Acta Phytotaxonomica Sinica 8, 331-42 (in Chinese with English abstract).

LI, C. Y., WANG, Q., LiU, X. Y. \& TANG, Y. Q. 1982. Explanatory notes to the tectonic map of Asia. Research Institute of Geology. Chinese Academy. Geological Science Cartography Publishing House, Beijing (in Chinese and English).

LI, C. Y. \& WANG, Q. 1983. The palaeo-plate tectonics of Northern China. No. 1, 3-16. Geological Publishing House, Beijing (in Chinese with English summary).

LIN, B. Y. et al. 1983. The Silurian System of China. Stratigraphy of China. No. 6, 1-245. Geological Publishing House, Beijing (in Chinese).

MCKerrow, W. S. \& SCotese, C. R. 1990. Palaeozoic palaeogeography and biogeography. The Geological Society of London. Memoir no. 12.

Mu, E. A., Chen, X., Ni, Y. N. \& RonG, J. Y. 1982. Subdivision and correlation chart in China with explanatory text (ed. by Nanjing Institute of Geology \& Palaeontology Academia Sinica). 73-89. Scientific Press (in Chinese).

Mu, E. A., Boucot, A. J., Chen, X. \& Rong, J. Y. 1986. Correlation of the Silurian rocks of China (A part of the Silurian correlation for East Asia). Geological Society of America, Special Paper 202.

NAGY, E. 1965. The microplankton occurring in the Neogene of the Meczek Mountains. Acta Botanica Hungarica 11, 197-232.

Nikitin, I. F. \& Bandaletov, S. M. 1986. The Tokrau horizon of the Upper Silurian. Series: Balkhash segment, Atma-Atma, Nauk, 1-236 (in Russian).

Obrhel, J. 1962. Die Flora der Pridoli-Schichten (BudnanyStufe) des mittelböhmishen Silurs. Geologie 11, 83-97.

Q1aO, X. D. 1983. Graptolites. In Palaeontological Atlas of Xinjiang, Vol. II. Late Palaeozoic section. Geological Publishing House, Beijing (in Chinese).

Richardson, J. B. \& MCGregor, D. C. 1986. Silurian and Devonian spore zones of the Old Red Sandstone
Continent and adjacent regions. Geological Survey of Canada Bulletin 364, 1-79.

Rong, J. Y. \& CHEN, X. 1992. Present and past of Silurian researches in China. Acta Palaeontologica Sinica 29, 385-401 (in Chinese with English summary).

SCHWEITZER, H.-J. 1983. Die Unterdevon Flora des Rheinlandes. Palaeontographica, Abteiling $B$ 189, 1-138.

SCOTESE, C. R. \& MCKerRow, W. S. 1990. Revised world maps and introduction. In Palaeozoic Palaeogeography and Biogeography (eds W. S. McKerrow and C. R. Scotese), pp. 1-21. Geological Society of London Memoir no. 12

SCOTESE, C. R. \& MCKerrow, W. S. 1991. Ordovician plate tectonic reconstructions. In Advances in Ordovician Geology (eds C. R. Barnes and S. H. Williams). Geological Survey of Canada, Paper 90-9.

Senkevich, M. A. 1975. New Devonian psilophytes from Kazakhstan. Eshlg Vses Palaeontol Obschetva 21, 288-9 (in Russian).

SENKEvICH, M. A. 1986. Fossil plants in the Tokrau horizon of the Upper Silurian. In The Tokrau horizon of the Upper Silurian Series: Balkhash Segment (eds I. F. Nikitin and S. M. Bandaletov). Alma-Ata, Nuka. 236 pp. (in Russian).

Shute, C. H. \& EDwards, D. 1989. A new rhyniopsid with novel sporangium organization from the Lower Devonian of South Wales. Botanical Journal of the Linnean Society 100, 111-37.

Tims, J. D. \& Chambers, T. C. 1984. Rhyniophytina and Trimerophytina from the early land flora of Victoria, Australia. Palaeontology 27, 265-79.

Wilde, P., Berry, W. B. N. \& Quinby-Hut, M. S. 1991. Silurian oceanic and atmospheric circulation and chemistry. In The Murchison Symposium: proceedings of an international conference on The Silurian System, pp. 123-143. Special Papers in Palaeontology 44.

Yurina, A. L. 1969. Devonian floras of central Kazakhstan. Materiely po geologii Shentral 'nogo Kazakhstana 8, 1-208.

ZHENG, Y. S. \& XIAO, S. L. 1979. The Devonian System of Xinjiang. In Regional Geological Survey of Xinjiang, Special Volume Stratigraphy no. 2 (in Chinese) 